\title{
An unusual course of SARS-CoV-2 infection: Challenging diagnosis of Guillain-Barré Syndrome
}

\author{
Ayca KOCA $^{\mathbf{1}}($ ID) \\ Leyla TALAN ${ }^{2}($ ID) \\ Turgut ŞAHIN ${ }^{3}$ (ID) \\ Güle ÇINAR ${ }^{4}$ (ID) \\ Ebru EVREN ${ }^{5}(I D)$ \\ Zeynep Ceren \\ KARAHAN $^{5}$ (ID) \\ Müge GÜNALP' ${ }^{1}(I D)$ \\ Neriman Defne \\ ALTINTAS $^{2}$ (ID) \\ Özden ŞENER ${ }^{3}$ (ID)
}

${ }^{1}$ Department of Emergency Medicine, Ankara University Faculty of Medicine, Ankara, Turkey

1 Ankara Üniversitesi Tıp Fakültesi, Acil Tıp Anabilim Dalı, Ankara, Türkiye

${ }^{2}$ Division of Intensive Care, Ankara University Faculty of Medicine, Ankara, Turkey

${ }^{2}$ Ankara Üniversitesi Tıp Fakültesi, Yoğun Bakım Bilim Dalı, Ankara, Türkiye

${ }^{3}$ Department of Neurology, Ankara University Faculty of Medicine, Ankara, Turkey

${ }^{3}$ Ankara Üniversitesi Tıp Fakültesi, Nöroloji Anabilim Dalı, Ankara, Türkiye

${ }^{4}$ Department of Infection Diseases and Clinical Microbiology, Ankara University Faculty of Medicine, Ankara, Turkey

${ }^{4}$ Ankara Üniversitesi Tıp Fakültesi, Enfeksiyon Hastalıkları ve Klinik Mikrobiyoloji Anabilim Dalı, Ankara, Türkiye

${ }^{5}$ Department of Medical Microbiology, Ankara University Faculty of Medicine, Ankara, Turkey

${ }^{5}$ Ankara Üniversitesi Tıp Fakültesi, Tıbbi Mikrobiyoloji Anabilim Dalı, Ankara, Türkiye

\section{ABSTRACT}

An unusual course of SARS-CoV-2 infection: Challenging diagnosis of Guillain-Barré Syndrome

COVID-19, caused by severe acute respiratory syndrome coronavirus-2, typically presents with respiratory symptoms and fever, but still a variety of clinical presentations have been reported. In this study, it was aimed to report a case of COVID-19 with an atypical presentation and an atypical course. As well, the recovery phase was complicated with GBS and consequently cytomegalovirus infection. It should be kept in mind that patients with COVID-19 severe disease need to be followed for neurological and other complications which may arise during the course of critical illness.

Key words: COVID-19; cytomegalovirus; guillain-barré syndrome; severe acute respiratory syndrome

ÖZ

SARS-CoV-2 enfeksiyonunun olağandışı seyri: Guillain-Barré sendromunun zorlu teşhisi

COVID-19 tipik olarak solunum semptomları ve ateşle kendini göstermekte bununla beraber çeşitli klinik bulgular bildirilmiştir. Atipik bir başlangıç ve 
atipik bir seyir ile takip edilen COVID-19 vakası bildiriyoruz. Ayrıca iyileşme süreci de GBS ve eş zamanlı sitomegalovirüs enfeksiyonu ile seyretti. Ağır COVID-19 hastalarının kritik hastalık seyrinde ortaya çıkabilecek nörolojik ve diğer komplikasyonlar açııından takip edilmesi gerektiği unutulmamalıdır.

Anahtar kelimeler: COVID-19; sitomegalovirüs; guillain-barré sendromu; ağır akut solunum yetmezliği

\section{INTRODUCTION}

The outbreak of severe acute respiratory syndrome coronavirus-2 (SARS-CoV-2) started at the end of 2019. In late January 2020, the World Health Organization declared the coronavirus disease-19 (COVID-19) a public health emergency and by March 2020 it was declared as a pandemic (1). COVID-19 typically presents with respiratory symptoms and fever, but still atypical presentations with various manifestations have been reported. The nature of neurological involvement in COVID-19 has not been thoroughly elucidated, and data on peripheral neuromuscular events are even more inconclusive.

However, new cases with peripheral nerve diseases such as Guillain-Barré Syndrome (GBS) and MillerFischer Syndrome have been reported recently (2-4). Here, we aimed to report the first case of COVID-19 in our institution, whose disease demonstrated an atypical course, with GBS that developed during the recovery phase of COVID-19.

\section{CASE REPORT}

A 70-year-old male patient was admitted to our emergency department on $13^{\text {th }}$ of March 2020 with acute shortness of breath and coughing. Previous medical history included recurrent hospitalizations with chronic obstructive pulmonary disease exacerbation and ischemic heart disease complicated with heart failure. The patient had no history of traveling abroad or exposure to patients infected with COVID-19. No fever was reported.

At the time of admission, testing for SARS-CoV-2 was not considered since the national algorithm requested presence of travel history to China or exposure to infected patients. Physical examination revealed a body temperature of $36.8^{\circ} \mathrm{C}$, pulse of 85 beats per minute, blood pressure of 136/77 $\mathrm{mmHg}$ and oxygen saturation of $95 \%$ breathing ambient air. The patient was oriented and well cooperated, lung auscultation revealed rhonchi and minimal crackles. All other findings were normal. On laboratory workup, white blood cell count was $14.10^{9}$, C-reactive protein (CRP) and serum procalcitonin levels were low $(5 \mathrm{mg} / \mathrm{L}$ and 0.2 $\mathrm{ng} / \mathrm{ml}$, respectively). Chest X-ray (CXR) revealed left paracardiac infiltration. Treatment with ceftriaxone and oseltamivir was started. Next day, acute phase reactants had risen rapidly to $297 \mathrm{mg} / \mathrm{L}$ for CRP, and 22 $\mathrm{ng} / \mathrm{ml}$ for procalcitonin. Sputum culture revealed growth of Streptococcus pneumoniae. In order to clearly define the lesion seen on CXR and rule out pulmonary thromboembolism, a contrast enhanced computer tomography (CT) was performed. Pulmonary CT revealed no defect compatible with acute thromboembolism in the main pulmonary artery lobar branches, however the middle lobe and lingula segment branches demonstrated blunt termination that might be compatible with embolism. As well, there were patchy areas of consolidation and congested groundglass opacities in the left lung upper lobe apicoposterior segment, middle lobe, lingula and bilateral lower lobes. Antibiotic therapy was escalated to meropenem, antiviral treatment was continued and patient was anticoagulated. On day five, the patient deteriorated and developed fever $\left(37.7^{\circ} \mathrm{C}\right)$, tachypnea and tachycardia. Because of progression on control CXR and worsening of respiratory symptoms, pulmonary $\mathrm{CT}$ was repeated. It revealed remarkable progress in findings compared to the previous examination, compatible with viral pneumonia, and testing for COVID-19 was recommended (Figure 1A). A combined nasopharyngeal + oropharyngeal swab sample was obtained for SARS-CoV-2 testing by reverse transcriptase polymerase chain reaction (RT-PCR) testing and the patient was transferred to the intensive care unit (ICU). He was admitted to a negative pressure airborne-isolation room as a suspected case of COVID-19. On admission, the patient was disoriented, confused and agitated, and was severely dyspneic with labored breathing. He was intubated and mechanical ventilation was started as recommended in the guidelines (5). Laboratory studies revealed lymphocytopenia $\left(0.21 \times 10^{9} / \mathrm{L}\right.$, normal: $\left.1.5-4 \times 10^{9} / \mathrm{L}\right)$, and elevated acute phase reactants (CRP: $132 \mathrm{mg} / \mathrm{L}$, procalcitonin: 8.03 $\mathrm{ng} / \mathrm{ml})$. The presence of SARS-CoV-2 RNA in the patient's swab sample was evaluated by BioSpeedy (Bioksen, Turkey) RT-PCR kit and was found positive. Antimicrobial therapy, including oseltamivir, lopinavir/ 
ritonavir, meropenem and tigecycline was ordered. On the second day of the treatment, lopinavir/ritonavir was changed to hydroxychloroquine and azithromycin combination since lopinavir/ritonavir bioavailability was significantly reduced when crushed to administer by feeding tube. The patient was sedated with midazolam and fentanyl infusions, daily awakening trials were not possible due to high inspiratory drive and elevated inspiratory pressures. A CT on the $21^{\text {th }}$ day revealed improvement of lung lesions (Figure 1A). The need for respiratory support had decreased; however, SARS-CoV-2 RNA in oropharyngeal swab remained positive on days 13 and 16 .

Starting on day 15 , the patient was weaned of sedatives and he gradually awakened within two days. Despite being alert and responsive with spontaneous movements of the head and trunk, no movement was possible in the four extremities. Neurological examination disclosed flask tetraplegia and areflexia (with absent deep tendon reflexes). A cranial CT and lumbar puncture were performed. Cranial CT was unremarkable except chronic ischemic encephalomalacia in the right occipital lobe and diffuse cerebral atrophy (Figure
1B). Cerebrospinal fluid analysis showed normal cell counts $\left(2 \times 10^{6} / \mathrm{L}\right.$, normal range: $\left.0-8 \times 10^{6} / \mathrm{L}\right)$ and mild protein elevation $(63 \mathrm{mg} / \mathrm{dl}$, normal range: $15-45 \mathrm{mg} /$ dl). A bedside electrophysiologic study presented sensory and motor distal conduction slowing as well as compound muscle action potential amplitude loss with predominant dispersion suggesting distal demyelination, $F$ waves were diffusely absent. Electromyography showed no signs of denervation and axonal degeneration were noted (Table 1). These findings supported a demyelinating sensorimotor polyradiculoneuropathy. The patient was diagnosed with GBS and plasma exchange treatment was started immediately. On day 31, the patient was extubated and RT-PCR still tested positive in combined swab sample. The patient responded poorly to five sessions of plasma exchange therapy, which was then followed by intravenous immunoglobulin treatment. Meanwhile, he tested negative on RT-PCR testing on days 39 and 41. However, pancytopenia developed, and since he was considered a chronic critically ill patient, a control CMV PCR was requested. Quantitative CMV-PCR testing was performed using Artus CMV QSRGQ kit
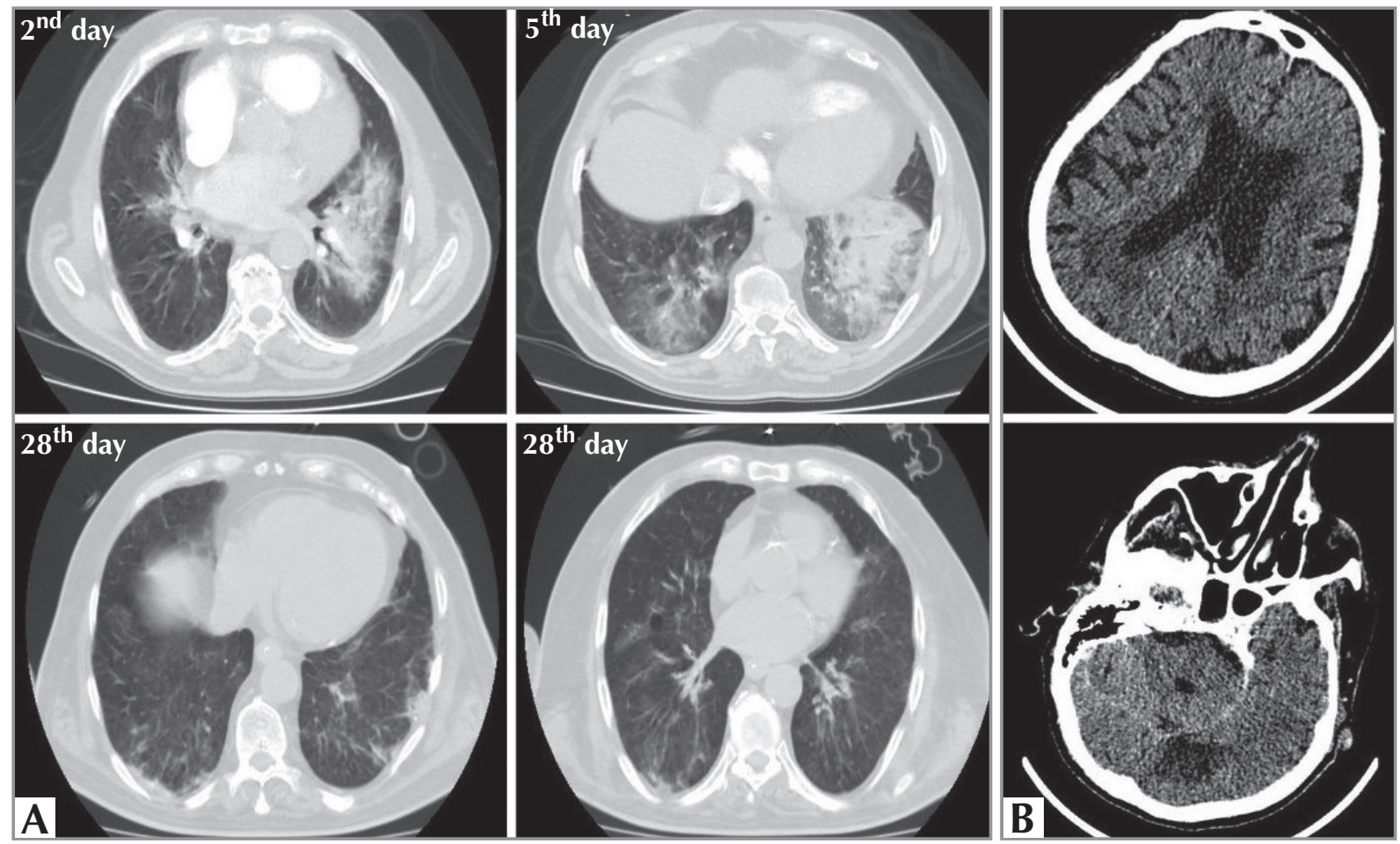

Figure 1. Chest and cranial computer tomography imaging. A. Chest CT images showing patchy consolidation along with groundglass opacities in the left upper lobe, middle lobe, lingula and bilateral lower lobes of the lung which were regressed considerably at the $28^{\text {th }}$ day of admission. B. Non-contrast brain CT images showing encephalomalacia in the left occipital lobe and diffuse cerebral atrophy. 
Table 1. Cerebrospinal fluid analysis and electromyography

\begin{tabular}{|c|c|c|c|c|c|}
\hline \multicolumn{6}{|c|}{ CSF findings } \\
\hline Opening pressure & \multicolumn{3}{|c|}{$10 \mathrm{~cm}-\mathrm{H}_{2} \mathrm{O}$} & & \\
\hline Macroscopic features & \multicolumn{3}{|c|}{ Clear, colorless } & & \\
\hline Cell count & \multicolumn{2}{|r|}{$2 / \mathrm{hPF}$} & & & \\
\hline Protein & \multicolumn{2}{|r|}{$63 \mathrm{mg} / \mathrm{dl}$} & & & \\
\hline Glucose (ratio of blood glucose) & \multicolumn{2}{|c|}{$79 \mathrm{mg} / \mathrm{dl}(0.62)$} & & & \\
\hline Chloride & \multicolumn{2}{|r|}{$128 \mathrm{mEq} / \mathrm{L}$} & & & \\
\hline Bacterial culture & \multicolumn{2}{|r|}{ Negative } & & & \\
\hline Lactate dehydrogenase & \multicolumn{2}{|r|}{$<25 \mathrm{U} / \mathrm{L}$} & & & \\
\hline \multirow[t]{2}{*}{ SARS-CoV-2 PCR } & \multicolumn{3}{|c|}{ Negative } & & \\
\hline & \multicolumn{3}{|c|}{ NCS and needle EMG findings } & & \\
\hline \multicolumn{6}{|l|}{ Sensory NCS } \\
\hline Nerve (recording site) & Amp. $(\mu \mathrm{v})$ & $\mathrm{CV}(\mathrm{m} / \mathrm{s})$ & & & \\
\hline Left Ulnar Nerve ( $5^{\text {th }}$ finger $)$ & 10 & 33 & & & \\
\hline Left Median Nerve (thumb) & 11 & 30 & & & \\
\hline \multicolumn{6}{|l|}{ Motor NCS } \\
\hline Nerve (muscle) & $\mathrm{DML}(\mathrm{ms})$ & Amp. $(\mu \mathrm{V})$ & $\mathrm{CV}(\mathrm{m} / \mathrm{s})$ & F-wave lat. (ms) & CMAP wave form \\
\hline Left ulnar (abductor digiti minimi) & 5.8 & $117 / 109$ & 53 & - & Disperse \\
\hline Left median nerve (abductor pollicis brevis) & 4.8 & $233 / 200$ & 48 & - & Disperse \\
\hline Left peroneal nerve (tibialis anterior) & 6.7 & 217 & - & - & Disperse \\
\hline \multicolumn{6}{|l|}{ Needle EMG } \\
\hline Muscle & \multicolumn{2}{|c|}{ Resting activity } & & $\mathrm{Fb} / \mathrm{psw}$ & MUP \\
\hline Left tibialis anterior & \multicolumn{2}{|c|}{ Silent } & & - & - \\
\hline Left vastus medialis & \multicolumn{2}{|c|}{ Silent } & & - & - \\
\hline Left abductor digiti minimi & \multicolumn{2}{|c|}{ Silent } & & - & - \\
\hline Left biceps brachii & \multicolumn{2}{|c|}{ Silent } & & - & - \\
\hline
\end{tabular}

(Qiagen, Germany) and the result was reported as 156.000 copies $/ \mathrm{ml}(255840 \mathrm{IU} / \mathrm{ml})$. Valganciclovir was started; however, the patient was lost on the $50^{\text {th }}$ day of his stay after an abrupt deterioration, presumably due to an acute coronary event.

\section{DISCUSSION}

Studies have demonstrated that SARS-CoV-2 infections can present with various manifestations of different severity, besides severe pneumonia (6). GBS can be triggered by a recent infection-induced immune attack that targets the peripheral nervous system. The abovementioned case is an example of the unusual course of SARS-CoV-2 infection. In our patient, generalized flaccid tetraplegia evolved during ICU stay. As a consequence of sedatives and neuromuscular blockers for management of his respiratory condition, his neurologic deterioration was noticed once sedation was stopped. Sedative treatment can mask early signs of the GBS. Sensory loss was accepted to be present in our patient since he was not grimacing or reacting during therapeutic or diagnostic needle injections (e.g. drawing blood samples or radial artery puncture for blood gas analysis). This finding was a helpful clue that impelled us to a differential diagnosis. Generalized weakness in the ICU should prompt primarily the diagnosis of critical illness neuropathy and myopathy (CINM). CINM can be a challenging diagnosis in the $\mathrm{ICU}$, even if it causes more proximal than distal weakness, and its clinical differentiation from GBS can be difficult (7). However, electrophysiologic findings clearly presented a demyelinating polyradiculoneuropathy in this patient.

The interval of 10 days between the onset of viral illness and neurologic symptoms corresponds to expected time seen in the development of GBS due to other 
infections. GBS associated with SARS-CoV-2 has been reported in the literature; the patients described in these reports have limb weakness and paresthesia at presentation, and these neurologic symptoms are the leading cause of admission to the ED $(3,4)$. Dissimilarly, our patient was admitted with respiratory symptoms and neurologic findings were not recorded before being intubated. Recent COVID-19 case reports may reveal us that this infection might be far more than a respiratory disease. Heart disease, acute liver injury, ongoing gastrointestinal issues, skin manifestations, neurologic damage, and other problems are to be considered as unusual presentations of the disease (8).

Once the patient is critically ill, COVID-19 patients need also to be followed for complications of chronic critical illness. We consider that high CMV-DNA levels may point to an immunoparalytic state later in the disease course, which may be an important point to consider while planning immunomodulatory treatment for these patients.

Moreover, the persistence and clearance of viral RNA in COVID-19 remain unclear. Ling et al. have reported that the median time from the onset of symptoms to first negative RT-PCR results for oropharyngeal swabs of convalescent patients was 9.5 (6.0-11.0) days (9). Our patient remained positive until the $31^{\text {st }}$ day, and the first negative RT-PCR test result was reported on the $39^{\text {th }}$ day. We suggest that this case is representative of a long-term carrier. During the 2002-2004 outbreak caused by SARS-CoV, reports revealed that a significant proportion of SARS patients had detectable viral RNA for SARS-CoV in their clinical specimens for a substantial period of time (median time of RT-PCR reconversion: 30 days) $(10,11)$. Prudent monitoring of RT-PCR conversion for exploring the duration of infectivity in COVID-19 patients may help to understand clinical significance and management of this patients.

\section{CONCLUSION}

Patients infected with SARS-CoV-2 may present with a variety of clinical syndromes and a careful assessment of each organ system is vital for a complete management. As well, patients with severe disease need to be followed for complications which may arise during the course of a critical illness.

\section{CONFLICT of INTEREST}

The authors reported no conflict of interest related to this article.

\section{AUTHORSHIP CONTRIBUTIONS}

Concept/Design: AK, LT, TY

Analysis/Interpretation: AK, LT, TY

Data Acquisition: AK, LT, GÇ

Writing: AK, LT, TY

Critical Revision: ZCK, MG, NDA, EE

Final Approval: MG, NDA, ÖŞ

\section{REFERENCES}

1. Centers for Disease Control and Prevention (CDC). Ending home isolation for persons with COVID-19 not in healthcare settings. Available from: https://www.cdc.gov/coronavirus/2019-ncov/hcp/disposition-in-home-patients.htm/ (Accessed date: 23.03.2020).

2. Gutiérrez-Ortiz C, Méndez A, Rodrigo-Rey S, San PedroMurillo E, Bermejo-Guerrero L, Gordo-Mañas $R$, et al. Miller Fisher Syndrome and polyneuritis cranialis in COVID-19. Neurology 2020; 95(5): e601-e605.

3. Zhao H, Shen D, Zhou H, Liu J, Chen S. Guillain-Barré syndrome associated with SARS-CoV-2 infection: causality or coincidence? Lancet Neurol 2020; 19(5): 383-4.

4. Toscano G, Palmerini F, Ravaglia S, Ruiz L, Invernizzi P, Cuzzoni MG, et al. Guillain-Barre Syndrome associated with SARS-CoV-2. N Engl J Med 2020; 382(26): 2574-6.

5. Alhazzani $W$, Møller MH, Arabi YM, Loeb M, Gonh $M N$, Fan $E$, et al. Surviving sepsis campaign: guidelines on the management of critically ill adults with Coronavirus Disease 2019 (COVID-19). Intensive Care Med 2020: 1-34.

6. Dong X, Cao YY, Lu XX, Zhang J, Du H, Yan YQ, et al. Eleven faces of coronavirus disease 2019. Allergy 2020; 75(7): 1699-1709.

7. Wakerley BR, Yuki N. Mimics and chameleons in GuillainBarre and Miller Fisher syndromes. Pract Neurol 2015; 15(2): 90-9.

8. Helms J, Kremer S, Merdji H, et al. Neurologic features in severe SARS-CoV-2 infection. N Engl I Med, 2020; 382(23): 2268-70.

9. Ling $Y, X u S B$, Lin $Y X$, Tian D, Zhu ZQ, Dai $F H$, et al. Persistence and clearance of viral RNA in 2019 novel coronavirus disease rehabilitation patients. Chin Med J (Engl) 2020; 133(9): 1039-43.

10. Li Y, Hu Y, Yu Y, Zhang $X$, Li B, Wu J, et al. Positive result of Sars-Cov-2 in faeces and sputum from discharged patient with COVID-19 in Yiwu, China. I Med Virol 2020; 92(10): 1938-47.

11. Chu CM, Leung WS, Cheng VC, Chan KH, Lin AWN, Chan $V L$, et al. Duration of RT-PCR positivity in severe acute respiratory syndrome. Eur Respir J 2005; 25(1): 12-4. 